\title{
Recent Developments in United Nations Policy on Housing and Property Restitution for Refugee Return
}

\author{
Bret Thiele
}

\begin{abstract}
This article reviews recent developments at the United Nations on housing and property restitution for the return of refugees and Internally Displaced Persons (IDPS). In August 1998 the un Sub-Commission on the Promotion and Protection of Human Rights took an innovative step towards facilitating the voluntary return of refugees and IDPS with the adoption of UN Security Council Resolution 1998/26. A descriptive analysis of that resolution and the subsequent developments at the United Nations are presented. Further, the article advocates and solicits support for continued United Nations developments in this regard.
\end{abstract}

\section{Résumé}

Cet article passe en revue les développements récents aux Nations Unies sur la question du logement et de la restitution de propriétés en ce qui concerne les réfugiés et les déplacés internes (DI). Au mois d'août 1998, la Souscommission des Nations Unies sur la promotion et la protection des droits de l'homme a adopté la résolution 1998/26 - une initiative toute à fait nouvelle pour faciliter le retour volontaire de réfugiés et de déplacés internes. Sont proposés ici une analyse descriptive de cette résolution ainsi que les développements qui ont eu lieu par la suite aux Nations Unies. En plus, l'article préconise - et lance un appel en ce sens - qu'il y ait des progrès continuels aux Nations Unies à cet égard.
$A$ ccording to the UN High Commissioner for Refugees, there are over 21 million persons currently displaced from their homes and living as refugees or internally displaced persons (IDPS). ${ }^{1}$ Many have been languishing in refugee camps or other makeshift accommodations for years. ${ }^{2}$ Refugees and IDPs often face indifference from the states in which their homes are located or, worse, are subject to outright hostility. Most of the displaced simply desire to return home in safety and dignity. The international community, however, has thus far been unable or unwilling to make this desire a reality.

The right of refugees and IDPs to return voluntarily has long been recognized as one of the best durable solutionsif not the best-for cases of mass displacement. ${ }^{3}$ Refugees and IDPs, however, have all too often been denied this right. ${ }^{4}$ Without adequate, consistent, and coordinated methods to ensure housing and property restitution, return is simply not possible for many refugees and IDPS.

Fortunately, human rights advocates, including the Centre on Housing Rights and Evictions (COHRE) 5 and Habit International Coalition, have begun to address the problem of housing and property restitution. In response to recent lobbying efforts, the United Nations Sub-Commission on the Promotion and Protection of Human Rights ${ }^{6}$ (referred to hereafter as the Sub-Commission) has initiated the development of an international norm for housing and property restitution in the context of the return of refugees and IDPs. Further, the Sub-Commission and several non-governmental organizations (NGOS) have requested that the United Nations Commission on Human Rights 
(referred to hereafter as the Commission) also address this problem. It is the hope of a growing number of human rights advocates that this norm will not only change the discourse surrounding refugee and IDP concerns, but have a real impact on the lives of millions of persons forced from their homes.

The Sub-Commission is a subsidiary body of the Commission and consists of twenty-six human rights experts from around the world. A key role of the Sub-Commission is to apply its expertise to relevant human rights issues and to advise the Commission.

The Commission is composed of fifty-three membergovernments and has a mandate to set international standards and monitor human rights. In recent years the Commission has reduced efforts to set standards and has turned its attention toward implementation. To this end, the Commission has increasingly addressed the needs of states by providing advisory services and technical assistance.

\section{UN Sub-Commission, 1998}

At its fiftieth session, the Sub-Commission took an innovative step towards facilitating the voluntary return home of refugees and IDPs with its adoption on August 26, 1998, of Resolution 1998/26.7 This resolution was strongly supported by this body of human rights experts and in fact was co-sponsored by over half of the Sub-Commission's members. ${ }^{8}$ In the resolution, entitled Housing and Property Restitution in the Context of the Return of Refugees and Internally Displaced Persons, the Sub-Commission reaffirmed the right of all refugees and internally displaced persons to return to their homes and places of habitual residence in their country or place of origin. ${ }^{9}$ This is a pressing issue, particularly in countries such as the former Republic of Yugoslavia, Rwanda, and Bhutan, where the right to return has been routinely jeopardized or denied outright due to circumstances that include a lack of government will and international coordination. Though addressing this issue generally, the Sub-Commission's resolution went one important step further by urging all states to ensure the free and fair exercise of the right to return to one's home and place of habitual residence by all refugees and internally displaced persons and to develop effective and expeditious legal, administrative, and other procedures to ensure the free and fair exercise of this right, including fair and effective mechanisms to resolve outstanding housing and property problems. ${ }^{10}$

This resolution tackles one of the most difficult problems currently facing the un High Commissioner for Refu- gees and other organizations trying to achieve the return with dignity of refugees and IDPs to their homes and places of habitual residence.

In another novel step, the resolution addresses the lack of coordinated international methods by inviting the United Nations High Commissioner for Refugees, in consultation with the United Nations High Commissioner for Human Rights, to develop policy guidelines to promote and facilitate the right of all refugees and, if appropriate to her mandate, internally displaced persons, to return freely, safely and voluntarily to their homes and places of habitual residence. ${ }^{11}$

\section{UN Commission on Human Rights, 1999}

The Sub-Commission's resolution laid the strategic foundation from which a joint state/NGo effort advanced. The effort was directed at getting the Commission to further entrench the right to housing and property restitution as an internationally recognized norm by adopting a resolution of its own.

The Republic of Georgia, with the assistance of COHRE, took the lead in this effort. The Republic of Georgia has an interest in the creation of international norms and guidelines as methods of facilitating the return of refugees and IDPs. Since 1991, Georgia experienced internal strife in the regions of Abkhazia and south Ossetia. ${ }^{12}$ This dispute has resulted in the displacement of 230,000 persons from the contested regions. ${ }^{13}$

As representatives of an observer government, and thus unable to formally submit a resolution to the Commission, the Georgian delegation had to seek co-sponsorship from governments with member status. ${ }^{14}$ This seemingly simple task proved difficult in the political environment of the Commission. Though expressing general support, some member governments suggested that the language of the draft resolution needed to be altered to more precisely define the rights that form the resolution's foundation. Specifically, several governments required that the rights affirmed in the operative paragraphs be explicitly defined by linking them to existing international instruments. The Georgian delegation also encountered resistance from some governments that have traditionally sought to block any efforts at promoting and protecting economic, social, and cultural rights, such as the right to adequate housing. The delegations from Austria and the United States proved particularly resistant to the draft resolution, though the latter expressed some concern about U.S. business property that may be affected by the dispute in the Republic of Georgia - a subject of no relevance to a draft resolution on hous- 
ing and property restitution in the context of refugee and IDP return. In light of this criticism, it was suggested that the Sub-Commission further consider the right to return for refugees and IDPs and take steps to further define the problems and issues involved with the right to return.

Consideration of Georgia's draft resolution was essentially killed when the Commission adopted Resolution 1999/ 47 on April 27, 1999, which merely noted "Sub-Commission Resolution 1998/26 on housing and property restitution in the context of the return of refugees and internally displaced persons" ${ }^{15}$ and encouraged the Sub-Commission "to continue its work on this matter." ${ }^{\prime 16}$

The Commission thus had the opportunity to affirm the right of return for refugees and IDPS and strengthen that right by articulating specific standards to facilitate the safe return of refugees and IDPs. Unfortunately, however, the Commission squandered this opportunity. The fact that the Commission failed to act, while at the same time expressing alarm over the ethnic cleansing and resulting refugee flow then occurring in Kosovo, is perhaps short-sighted and certainly inconsistent with its mandate.

It is surprising that the Commission did not seriously consider adopting the draft resolution. The rights affirmed in the operative paragraphs were not novel, nor were they obscure, but rather legal terms defined in the Universal Declaration of Human Rights, the International Covenant on Civil and Political Rights, and the International Covenant on Economic, Social, and Cultural Rights. ${ }^{17}$ In addition, the resolution would help achieve goals enumerated in the Vienna Declaration and Programme of Action, in particular the right of refugees to return to their countries ${ }^{18}$ and ensure that IDPS can voluntarily and safely return home. ${ }^{19}$

Furthermore, the resolution would universally establish the standards expressed in a number of highly regarded regional instruments, including annex 7 of the Dayton Peace Accords ${ }^{20}$ addressing Bosnia-Herzegovina, the Arusha Peace Agreement of August 1993 addressing Rwanda, ${ }^{21}$ and the C.E.A.R.-C.C.P.P. Agreement of October $1992^{22}$ addressing Guatemala.

\section{UN Sub-Commission, 1999}

Pursuant to Commission Resolution 1999/47, the SubCommission again took up the cause of housing and property restitution for refugees and IDPs. Again, this cause garnered the support of a majority of the Sub-Commission's human rights experts. ${ }^{23}$

In an effort to address the concerns expressed by several governments at the Commission, the Sub-Commission adopted Decision 1999/108 on August 25, 1999, entitled Housing and Property Restitution in the Context of the Return of Refugees and Internally Displaced Persons. ${ }^{24}$ This decision expressly states the "increasing importance" of housing and property restitution for refugees and IDPs. Furthermore, the decision asks that the Commission solicit input from states, the Representative of the SecretaryGeneral on Internally Displaced Persons, inter-governmental organizations including the UN High Commissioner for Refugees, and non-governmental organizations regarding Sub-Commission Resolution 1998/26. In this way, the SubCommission aims to resubmit to the Commission a very important issue for the international community-a draft resolution articulating the definitive statement of the international community on housing and property restitution for returning refugees and IDPS.

\section{UN Commission on Human Rights, 2000}

The concept of housing and property restitution for returning refugees and IDPs received the support of Francis Deng, the Secretary-General's Representative on Internally Displaced Persons. In his report to the Commission, Mr. Deng also noted that this topic needed additional research, and he welcomed the fact that the Commission, in its Resolution 1999/47, encouraged the Sub-Commission to continue its work on this matter. ${ }^{25}$

The Commission's resolution on internally displaced persons requests that the un Secretary-General disseminate Resolution 1998/26 of the Sub-Commission on the Promotion and Protection of Human Rights, entitled Housing and Property Restitution in the Context of the Return of Refugees and Internally Displaced Persons. ${ }^{26}$ The goal of disseminating the resolution is to solicit comments from governments, NGOS, and other interested parties in order that the United Nations can formulate effective policy guidelines.

The Commission also adopted a resolution on the realization in all countries of the economic, social, and cultural rights contained in the Universal Declaration of Human Rights and in the International Covenant on Economic, Social, and Cultural Rights, and on the study of special problems faced by the developing countries in their efforts to achieve these human rights. ${ }^{27}$ Part of the resolution established the mandate for a special rapporteur on the right to adequate housing. The mandate of the special rapporteur, appointed for three years, is to report to the Commission on the status of the progressive realization of and developments relevant to housing rights; promote assistance to governments in their efforts to progressively se- 
cure housing rights; and develop a regular dialogue on possible areas of cooperation between governments, UN bodies, specialized agencies, international organizations such as the UN Centre for Human Settlements, NGOS, and international financial institutions. It is hoped that the special rapporteur can significantly contribute to resolving the difficult issues involved with housing and property restitution in the context of refugee and IDP return.

\section{Conclusion}

The Sub-Commission has already taken a significant step. It is now important for the Commission to reaffirm the right to housing and property restitution. This right can then be used as a basis to protect refugees and IDPs from the arbitrary deprivation of housing and property-a deprivation that all too often occurs purely because persons were forced by circumstances beyond their control to flee their homes to save their lives.

It is hoped that the work of the Sub-Commission and the newly appointed special rapporteur will lead to the Commission's reaffirmation of the principles previously expressed in Sub-Commission Resolution 1998/26. A Commission resolution will facilitate that body's often-repeated desire to see refugees and IDPs return to their homes in safety and in dignity. The Commission has expressly articulated that desire in a number of resolutions including 1999/2 of April 13, 1999, on human rights in Kosovo, ${ }^{28}$ 1998/ 69 of April 21, 1998, on human rights in Rwanda, ${ }^{29} 1998 / 70$ of April 21, 1998, on human rights in Afghanistan, ${ }^{30}$ and 1997/57 of April 15, 1997, on human rights in Bosnia and Herzegovina, the Republic of Croatia, and the Federal Republic of Yugoslavia (Serbia and Montenegro). ${ }^{31}$

If carried to completion in the Commission, this resolution will change the discourse on the right to return by creating an internationally recognized norm backed by the international community. More important, this resolution will change not only discourse but real world situations on the ground, by developing guidelines to promote and facilitate the right of all refugees and IDPs to return freely, safely, and voluntarily to their homes and places of habitual residence. Furthermore, the resolution will urge states and other relevant parties to ensure the free and fair exercise of the right to return to one's home and place of habitual residence by all refugees and IDPs and assist in the development of effective and expeditious legal, administrative, and other procedures to ensure the free and fair exercise of this right. By adopting its own resolution on this important subject, the Commission, representing the consensus of the international community, would significantly further the promotion and protection of the rights of refugees and IDPs.

\section{Endnotes}

1. The UN High Commissioner for Refugees notes over 18.2 million refugees and IDPS within its mandate. UNHCR, UNHCR by the Numbers: Persons of Concern to UNHCR at 1 January 1999 (1999). In addition, 3.2 million Palestinian refugees living in Jordan, Lebanon, Syria, the West Bank, and Gaza fall under the mandate of the Gaza-based United Nations Relief and Works Agency for Palestine Refugees in the Near East (UNRwA).

2. The un High Commissioner for Refugees currently assists approximately 4.5 million persons, with approximately 3.5 million residing in refugee camps. See UnHCR, Refugees and Others of Concern to UNHCR: 1998 Statistical Overview (1999).

3. For an examination of durable solutions to refugee and IDP crises, see UNHCR, "Issues: Durable Solutions," <http:// www.unhcr.ch/issues/durable/durable.htm $>$.

4. For an examination of the problems of return see UNHCR, "Return and Reintegration," chap. 4 in The State of the World's Refugees: A Humanitarian Agenda (1997), <http://www.unhcr.ch/ refworld/pub/state/97/ch4.htm >.

5. The Centre on Housing Rights and Evictions is a Geneva-based, international, non-government, human rights organization that addresses economic, social, and cultural rights generally, with a particular focus on the human right to adequate housing and on preventing forced evictions.

6. Formerly the Sub-Commission on Prevention of Discrimination and Protection of Minorities.

7. SC Res. 1998/26, UN Doc. E/CN.4/1999/4, E/CN.4/Sub.2/1998/ 45 at $72(1998)$.

8. SC Res. 1998/26 was adopted without a vote and was co-sponsored by Mr. Eide (Norway), Mr. Genot (Belgium), Mr. Goonesekere (Sri Lanka), Ms. Hampson (United Kingdom), Mr. Joinet (France), Ms. Koufa (Greece), Mr. Maxim (Romania), Mr. Mehedi (Algeria), Mr. Sang Yong Park (Republic of Korea), Mr. Sorabjee (India), Ms. Warzazi (Morocco), Mr. Weissbrodt (United States), Mr. Yimer (Ethiopia), and Mr. Yokota ( Japan). The resolution was ultimately adopted without a vote. See UN Doc. E/CN.4/1999/4, E/CN.4/Sub.2/1998/45 at p. 121 (1998).

9. SC Res. 1998/26, note 8 supra.

10. Ibid.

11. Ibid.

12. U.S. Department of State, Background Notes: Georgia, November 1998.

13. Ibid.

14. Though any government can co-sponsor a draft resolution, only member governments of the Commission may submit a draft resolution for consideration by the Commission as a whole.

15. CHR Res.1999/47, UN Doc. E/1999/23, E/CN.4/1999/167 (1999).

16. Ibid.

17. The resolution reaffirms the universal applicability of the right to adequate housing (as articulated in article 25 (1) of the Universal Declaration of Human Rights, and article 11 (1) of the International Covenant on Economic, Social and Cultural Rights), the right to freedom of movement (as articulated in article 13 (1) of the Universal Declaration of Human Rights, and article 12 (1) of the International Covenant on Civil and Political Rights), the right to choose one's residence (as articulated 
in article 12 (1) of the International Covenant on Civil and Political Rights), the right to privacy and respect for the home (as articulated in article 12 of the Universal Declaration of Human Rights, and article 17(1) of the International Covent on Civil and Political Rights), and the particular importance of these rights to returning refugees and internally displaced persons wishing to return to their homes and places of habitual residence.

18. Vienna Declaration and Programme of Action, UN Doc. A/ CONF.157/23 at sec. I:23 (1993).

19. Ibid.

20. According to article 1 (1) of annex 7, "[a]ll refugees and displaced persons have the right freely to return to their homes of origin." Article 1 (1), annex 7, Dayton Peace Accords. Furthermore, refugees and IDPs "shall have the right to have restored to them property of which they were deprived in the course of hostilities since 1991 and to be compensated for any property that cannot be restored to them." Ibid. For an analysis of article 1 (1) of annex 7, see Simon Bagshaw, "Benchmarks or Deutschmarks? Determining the Criteria for the Repatriation of Refugees to Bosnia and Herzegovina" (1997) 9 Int'l J. Refugee L. 566.

21. The Arusha Peace Agreement was signed on August 4, 1993, and received the overwhelming support of the United Nations. One of the four pillars of the Arusha Peace Agreement was the repatriation and resettlement of refugees and internally displaced persons. The Arusha Peace Agreement was never implemented although its principal provisions have begun to be implemented by the current Government of National Unity in Rwanda. For a detailed explanation of UN efforts to implement the Arusha Peace Agreement, see the Second Progress Report of the Secretary-General on the United Nations Assistance Mission for Rwanda, UN Doc. S/1994/360 (1994). See also GA Res. A/RES/ 49/23 (1994) (recognizing that the Arusha Peace Agreement provides an appropriate framework for national reconciliation).

22. The C.E.A.R.-C.C.P.P. Agreement was between the Guatemalan National Service Commission for Repatriates, Refugees, and the Displaced (C.E.A.R.) and the Permanent Commission of Guatemalan Refugees in Mexico (c.C.P.P.). For a detailed discussion of this agreement, see R. Andrew Painter, "Property Rights of Returning Displaced Persons: The Guatemalan Experience" (1996) 9 Harvard Hum. Rts. J. 145.

23. SC decision 1999/108 was adopted without a vote.

24. UN Doc. E/CN.4/sub.2/DEC/1999/108 (1999).

25. UN Doc. E/CN.4/2000/83, paras. 74-6 (2000).

26. CHR Res. 2000/53, UN Doc. E/CN.4/RES/2000/53 (2000).

27. CHR Res. 2000/9, UN Doc. E/CN.4/RES/2000/9 (2000).

28. CHR Res. 1999/2, UN Doc. E/1999/23, E/CN.4/1999/167 (1999) (underscoring the right of all refugees and internally displaced persons to return to their homes in safety and honour).

29. CHR Res. 1998/69, UN Doc. E/1998/23, E/CN.4/1998/177 (1998) (encouraging the Government of Rwanda to continue its efforts to improve the welfare ... especially [of] genocide survivors and returnees ... with particular attention to matters concerning property).

3o. CHR Res. 1998/70, UN Doc. E/1998/23, E/CN.4/1998/177 (1998) (urging all the Afghan parties to seek a comprehensive political solution leading to the voluntary return of displaced persons to their homes in safety and dignity).

31. CHR Res. 1997/57, UN Doc. E/1997/23, E/CN.4/1997/150 (1997) (calling on all authorities in Bosnia and Herzegovina to allow the return of refugees and displaced persons to their places of origin and to immediately cease actions that undermine the right to return, and to take immediate steps to repeal legislation that infringes on the right to return, including laws relating to "abandoned" property, to end illegal evictions of persons from their homes, and to reinstate in their homes persons who have been evicted in violation of their rights).

Bret Thiele is an international human rights lawyer currently working on human rights concerns of refugees, internally displaced persons, asylum-seekers, and asylees. Mr. Thiele is also an expert on United Nations human rights mechanisms. 